\title{
Clinical utility gene card for: Meckel syndrome
}

\author{
R Salonen ${ }^{\star, 1}$, M Kestilä ${ }^{2}$ and C Bergmann ${ }^{3}$ \\ European Journal of Human Genetics (2011) 19, doi:10.1038/ejhg.2010.255; published online 2 February 2011
}

\section{DISEASE CHARACTERISTICS}

1.1 Name of the disease (synonyms)

Meckel syndrome types 1-6, Meckel-Gruber syndrome, and dysencephalia splanchnocystica. ${ }^{1,2}$

\subsection{OMIM\# of the disease}

Type 1 MIM \#249000, type 2 MIM \#603194, type 3 MIM \#607361, type 4 MIM \#611134, type 5 MIM \#611561, and type 6 MIM \#612284.

1.3 Name of the analysed genes or DNA/chromosome segments MKS1, ${ }^{3-5}$ TMEM216 (MKS2), ${ }^{6}$ TMEM67 (MKS3), ${ }^{4,5,7}$ CEP290 (MKS4) ${ }^{8,9}$ RPGRIP1L (MKS5), ${ }^{10}$ and CC2D2A (MKS6). ${ }^{11}$

\subsection{OMIM\# of the gene(s)}

MKS1, MIM\# 609883; TMEM216, MIM\# 613277; TMEM67, MIM\# 609884; CEP290, MIM\# 610142; RPGRIP1L, MIM\# 610937; and CC2D2A MIM\# 612013.

\subsection{Mutational spectrum}

Data according to published literature and the HGMD database (release date 24 September 2010; https://portal.biobase-international.com)

MKS1: Major mutation c.1408-7_35del p.Gly470fs. In addition, 17 other mutations listed so far for patients with the Meckel-Gruber phenotype (three nonsense, one missense, seven canonical splice-site mutations, four small deletions/duplications, one silent mutation, and one intronic 143-bp deletion, both leading to aberrant splicing). ${ }^{3,12,13}$

TMEM216/MKS2: Three different mutations described so far in patients with Meckel-Gruber syndrome (one nonsense, one splicing, and one missense mutation). ${ }^{6}$

TMEM67/MKS3: Wide mutational spectrum without significant hotspot mutation in non-isolated cohorts. So far, 37 different mutations described in patients with the Meckel-Gruber phenotype (5 nonsense, 17 missense, 7 canonical splice-site mutations, 7 small deletions/insertions/duplications, and 1 gross deletion described at genomic DNA level encompassing exons 17-21). ${ }^{3,13,14}$

CEP290/MKS4: Recurrent mutation c.1219_1220del p.Met407fs in several families. A total of 13 different mutations described so far in patients with the Meckel-Gruber phenotype (five nonsense, two canonical splicesite mutations, and six small deletions/insertions/duplications). ${ }^{8,9}$

RPGRIP1L/MKS5: Only four different mutations in MKS cases described so far (three nonsense and one missense mutation).

CC2D2A/MKS6: Major mutation c.1762C > T p.Val587fs. In addition, 17 mainly family-specific mutations identified in patients with MKS (four nonsense, one missense, six splice-site mutations, five small deletions/insertions, and one gross deletion described at genomic DNA level encompassing exons 28-31). ${ }^{11,15}$

Currently, it is still hard to give exact figures on the contribution of each of the above genes to the total mutational load in Meckel-Gruber syndrome. There will be further genetic heterogeneity. However, MKS1, MKS3/TMEM67, and MKS6/CC2D2A might be major MKS genes, followed by MKS4/CEP290.,11,15,16 Currently, the role of MKS2/TMEM216 in Meckel-Gruber syndrome can only be speculated upon, whereas MKS5/RPGRIP1L seems to be quite rarely mutated in typical cases of Meckel syndrome.

Mutations in all MKS genes are mainly truncating, whereas in $\mathrm{MKS} 3$ missense mutations are also frequent.

\subsection{Analytical methods}

Consanguineous and multiplex pedigrees were assessed using initial linkage analysis of known loci with subsequent sequencing in case of compatible haplotypes.

Mainly sequencing was carried out in sporadic cases originating from non-consanguineous marriages because of family-specific mutations in most cases.

\subsection{Analytical validation}

Most of the mutations have been identified on research basis by sequencing using a protocol that is validated in most laboratories.

\subsection{Estimated frequency of the disease}

(incidence at birth ('birth prevalence') or population prevalence) $1 / 20000$.

1.9 If applicable, prevalence in the ethnic group of the investigated person:

In Finland and other isolated and/or consanguineous cohorts, the prevalence was much more frequent (most probably $>1 / 5000-10000$ ).

\subsection{Diagnostic setting:}

\begin{tabular}{lll}
\hline & Yes & No \\
A. (Differential) diagnostics & $\bigotimes$ & $\square$ \\
B. Predictive testing & $\square$ & $\square$ \\
C. Risk assessment in relatives & $\bigotimes$ & $\square$ \\
D. Prenatal & $\bigotimes$ & $\square$
\end{tabular}

Comment: If the causative gene and mutation of MKS can be identified, carrier screening of the relatives becomes possible as well as molecular prenatal diagnosis and preimplantation diagnosis.

\footnotetext{
${ }^{1}$ Department of Medical Genetics, Väestöliitto, Helsinki, Finland; ${ }^{2}$ National Institute for Health and Welfare, Department of Chronic Disease Prevention, Helsinki, Finland and ${ }^{3}$ Center for Human Genetics, Bioscientia, Ingelheim, Germany

*Correspondence: Dr R Salonen or Professor C Bergmann, Department of Medical Genetics, Väestöliitto, Kalevankatu 16, PO Box 849, Helsinki 00101, Finland.

E-mail: riitta.salonen@vaestoliitto.fi or carsten.bergmann@bioscientia.de
} 


\section{TEST CHARACTERISTICS}

\begin{tabular}{|c|c|c|c|c|}
\hline & \multicolumn{2}{|c|}{ Genotype or disease } & \multirow{2}{*}{$\begin{array}{l}\text { A: True positives } \\
\text { B: False positives }\end{array}$} & \multirow{2}{*}{$\begin{array}{l}\text { C: False negative } \\
\text { D: True negative }\end{array}$} \\
\hline & Present & Absent & & \\
\hline \multicolumn{5}{|l|}{ Test } \\
\hline \multirow[t]{2}{*}{ Positive } & A & B & Sensitivity: & $A /(A+C)$ \\
\hline & & & Specificity: & $D /(D+B)$ \\
\hline \multirow[t]{2}{*}{ Negative } & $\mathrm{C}$ & $\mathrm{D}$ & Positive predictive value: & $A /(A+B)$ \\
\hline & & & Negative predictive value: & $D /(C+D)$ \\
\hline
\end{tabular}

2.1 Analytical sensitivity

(proportion of positive tests if the genotype is present)

Nearly $100 \%$.

2.2 Analytical specificity

(proportion of negative tests if the genotype is not present)

Nearly $100 \%$.

\subsection{Clinical sensitivity}

(proportion of positive tests if the disease is present)

Clinical sensitivity can be dependent on variable factors, such as age or family history. In such cases a general statement should be given, even if a quantification can only be made case by case.

Clinical sensitivity is not known so far. Currently, six genes with a number of mutations have been identified as the causes of Meckel syndrome. There is a big variation in the distribution of these mutations in different populations, and some additional genes are still to be identified. ${ }^{6,16,17}$

\subsection{Clinical specificity}

(proportion of negative tests if the disease is not present)

Clinical specificity can be dependent on variable factors, such as age or family history. In such cases a general statement should be given, even if a quantification can only be made case by case.

Nearly $100 \%$.

2.5 Positive clinical predictive value (lifetime risk to develop the disease if the test is positive) $100 \%$.

2.6 Negative clinical predictive value (probability not to develop the disease if the test is negative) Assume an increased risk based on family history for a nonaffected person. Allelic and locus heterogeneity may need to be considered.

Index case in that family had been tested:

Much $<1 \%$.

Index case in that family had not been tested:

Unknown.

\section{CLINICAL UTILITY}

3.1 (Differential) diagnosis: The tested person is clinically

affected

(To be answered if in 1.10 'A' was marked)

Yes.

\subsubsection{Can a diagnosis be made other than through a genetic test?}

$\begin{array}{ll}\text { No } & \square \text { (continue with 3.1.4) } \\ \text { Yes } & \\ \text { Clinically } & \\ \text { Imaging } & \square \\ \text { Endoscopy } & \square \\ \text { Biochemistry } & \square \\ \text { Electrophysiology } & \square \\ \text { Other (please describe) } & \text { Autopsy and histological verification of the typical } \\ & \text { findings is reasonable. }\end{array}$

3.1.2 Describe the burden of alternative diagnostic methods to the patient?

The condition is lethal.

3.1.3 How is the cost effectiveness of alternative diagnostic methods to be judged?

3.1.4 Will disease management be influenced by the result of a genetic test?

$\begin{array}{ll}\text { No } & \square \\ \text { Yes } & \bigotimes \\ \text { Therapy (please describe) } & \text { None in typical lethal cases } \\ \text { Prognosis (please describe) } & \text { Lethal in early infancy } \\ \text { Management (please describe) } & \text { None, termination of pregnancy in prenatally } \\ & \text { diagnosed cases }\end{array}$

3.2 Predictive setting: The tested person is clinically unaffected but carries an increased risk based on family history

(To be answered if in 1.10 ' $B$ ' was marked)

3.2.1 Will the result of a genetic test influence lifestyle and prevention?

Early prenatal diagnostics and preimplantation diagnosis become possible.

3.2.2 Which options in view of lifestyle and prevention does a person at-risk have if no genetic test has been done (please describe)?

Prenatal diagnosis by ultrasound scan and termination of pregnancy in case of an affected fetus.

3.3 Genetic risk assessment in family members of a diseased person (To be answered if in 1.10 ' $C$ ' was marked)

Yes, in genetic counselling carrier testing of family members becomes possible.

3.3.1 Does the result of a genetic test resolve the genetic situation in that family?

Yes.

3.3.2 Can a genetic test in the index patient save genetic or other tests in family members?

Yes.

3.3.3 Does a positive genetic test result in the index patient enable a predictive test in a family member?

No. 


\subsection{Prenatal diagnosis}

(To be answered if in $\mathbf{1 . 1 0}$ ' $\mathrm{D}$ ' was marked)

Early genetic testing from chorionic villi is possible. Ultrasound scan detects the multicystic kidneys and malformations of the head, brain, and extremities.

\subsubsection{Does a positive genetic test result in the index patient enable a prenatal diagnostic?}

Yes.

\section{IF APPLICABLE, FURTHER CONSEQUENCES OF TESTING}

Please assume that the result of a genetic test has no immediate medical consequences. Is there any evidence that a genetic test is nevertheless useful for the patient or his/her relatives? (Please describe)

Preimplantation diagnosis becomes possible.

\section{CONFLICT OF INTEREST}

The authors declare no conflict of interest.

\section{ACKNOWLEDGEMENTS}

This work was supported by EuroGentest, an EU-FP6 supported NoE, contract number 512148 (EuroGentest Unit 3: 'Clinical genetics, community genetics and public health', Workpackage 3.2 ).

1 Salonen R: The Meckel syndrome: clinicopathological findings in 67 patients. Am J Med Genet 1984; 18: 671-689.

2 Paavola P, Salonen R, Baumer A, Schinzel A, Boyd PA, Gould S et al:: Clinical and genetic heterogeneity in Meckel syndrome. Hum Genet 1997; 101: 88-92.

3 Kyttala M, Tallila J, Salonen R et al: MKS1, encoding a component of the flagellar apparatus basal body proteome, is mutated in Meckel syndrome. Nat Genet 2006; 38: 155-157.
4 Consugar MB, Kubly VJ, Lager DJ et al: Molecular diagnostics of Meckel-Gruber syndrome highlights phenotypic differences between MKS1 and MKS3. Hum Genet 2007; 121: 591-599.

5 Dawe HR, Smith UM, Cullinane AR et al: The Meckel-Gruber syndrome proteins MKS1 and meckelin interact and are required for primary cilium formation. Hum Mol Genet 2007; 16: 173-186.

6 Valente E M, Logan CV, Mougou-Zerelli S et al: Mutations in TMEM216 perturb ciliogenesis and cause Joubert, Meckel and related syndromes. Nat Genet 2010; 42: 619-625.

7 Smith UM, Consugar M, Tee LJ et al: The transmembrane protein meckelin (MKS3) is mutated in Meckel-Gruber syndrome and the wpk rat. Nat Genet 2006; 38: 191-196.

8 Baala L, Audollent S, Martinovic J et al: Pleiotropic effects of CEP290 (NPHP6) mutations extend to Meckel syndrome. Am J Hum Genet 2007; 81: 170-179.

9 Frank V, den Hollander AI, Bruchle N et al: Mutations of the CEP290 gene encoding a centrosomal protein cause Meckel-Gruber syndrome. Hum Mutat 2008; 29: 45-52.

10 Delous M, Baala L, Salomon R et al: The ciliary gene RPGRIP1L is mutated in cerebello-oculo-renal syndrome (Joubert syndrome type B) and Meckel syndrome. Nat Genet 2007; 39: 875-881.

11 Tallila J, Jakkula E, Peltonen L, Salonen R, Kestila M: Identification of CC2D2A as a Meckel syndrome gene adds an important piece to the ciliopathy puzzle. Am J Hum Genet 2008; 82: 1361-1367.

12 Frank V, Bruchle N, Mager S et al: Aberrant splicing is a common mutational mechanism in MKS1, a key player in Meckel-Gruber syndrome. Hum Mutat 2007; 28: 638-639.

13 Khaddour R, Smith U, Baala L et al: Spectrum of MKS1 and MKS3 mutations in Meckel syndrome: a genotype-phenotype correlation. Hum Mutat 2007; 28: 523-524.

14 lannicelli M, Brancati F, Mougou-Zerelli S et al: Novel TMEM67 mutations and genotype-phenotype correlates in meckelin-related ciliopathies. Hum Mutat 2010; 31: E1319-E1331.

15 Mougou-Zerelli S, Thomas S, Szenker E et al: CC2D2A mutations in Meckel and Joubert syndromes indicate a genotype-phenotype correlation. Hum Mutat 2009; 30: 1574-1582.

16 Tallila J, Salonen R, Kohlschmidt N, Peltonen L, Kestilä M: Mutation spectrum of Meckel syndrome genes: one group of syndromes or several distinct groups? Hum Mutat 2009; 30: E813-E830.

17 Bergmann C, Fliegauf M, Frank $V$ et al: Loss of nephrocystin-3 function can cause embryonic lethality, Meckel-Gruber-like syndrome, situs inversus, and renal-hepaticpancreatic dysplasia. Am J Hum Genet 2008; 82: 959-970. 